\title{
Bacterial Profile in Children Admitted with Septicaemia in a Semi Urban Hospital in South India
}

\section{Edwin Dias ${ }^{1}$, Deepak $\mathrm{K}^{2 *}$ and Sandeep Gada ${ }^{3}$}

${ }^{1}$ Professor and HOD, Department of Paediatrics, Srinivas Institute of Medical Science and Research Centre, Mangalore, India

${ }^{2}$ Junior Resident, Department of Paediatrics, Srinivas Institute of Medical Science and Research Centre, Mangalore, India

${ }^{3}$ Assistant Professor, Department of Paediatrics, Mahaveer Institute of Medical

Science, India

*Corresponding Author: Deepak K, Junior Resident, Department of Paediatrics, Srinivas Institute of Medical Science and Research Centre, Mangalore, India.
Received: June 03, 2021

Published: August 27, 2021

(C) All rights are reserved by Deepak K., et al.

\begin{abstract}
Background: Antibiotics resistance is an important reason why the bacterial profile of PICU is mandatory. Here we are studying the bacterial profile of PICU in a semi urban hospital in South India.

Objective: Is to study the bacteria and the culture and sensitivity reports in PICU.

Conclusion: The commonest organism causing sepsis in PICU is Coagulase negative Staphylococcus and this organisms have shown sensitivity to Amikacin.

The pathogenic bacterial aetiology of septicaemia is vast, thus every PICU should emphasize on the importance of a routine periodic testing of microbial bacterial spectrum and their sensitivity to drugs in order to formulate a selective antibiotic regimen for PICU.
\end{abstract}

Keywords: PICU; Coagulase Negative Staphylococcus; Septicaemia; Amikacin

\section{Introduction}

Fever is the most common symptom in a healthy young child to be brought to a paediatric emergency department [1,2]. The evaluation and management of a young child with fever is a common problem. It has been estimated that nearly 35\% of unscheduled ambulatory visits are for fever in children [2]. Bloodstream infection has been a primary concern of physicians for over 80 years. Blood cultures are usually done for the evaluation of sick children with or without evidence of a focus of infection [3]. Many serious infections are associated with bacteraemia and the blood culture may be positive even when cultures of the specimens taken from the local area of infection (cerebrospinal fluid, tissue aspirate, sy- novial fluid) are negative. A report of a positive blood culture without apparent site of infection usually prompts a clinical re-evaluation and search for a primary focus.

Septicaemia is a condition with a high mortality rate varying from $30-70 \%$ depending on virulence and pathogenicity of the organism and its host factors $[4,5]$. Blood infection is an important cause of death, giving a rate of 25 - 50\% [6]. More recently Bloomberg., et al. (2007) [7] reported a mortality of $40 \%$ in paediatric patients with laboratory confirmed bacteraemia. Bacterial pathogen isolation in blood culture is often associated with high morbidity and mortality among children [8]. In recent years, septicaemic infections due to Gram-positive cocci have increased antimicrobial 
resistance and frequency of cases seen [9]. Since the progressive increase in health care problems are related to bacteraemia in children, we attempted to investigate the incidence and pattern of bacteraemia and to determine the bacteriological profile and antibiotic sensitivity pattern in children aged weeks to years admitted to the PICU.

\section{Materials and Methods}

This study was conducted by analysing the blood culture and their sensitivity to antimicrobials, reports obtained during October 2017 to October 2020 from 100 children admitted to the PICU with suspected septicaemia. The patients were divided into two age groups 1month to 6 years and 6 years to 12 years. A second sample was collected on the same day to rule out contamination with the skin flora. Approximately 2cc of blood was drawn under aseptic precautions and inoculated into Brain Heart infusion broth, incubated at $37^{\circ} \mathrm{C}$ for $24 \mathrm{hrs}$. Subcultures were made on blood agar and MacConkeys agar after $24 \mathrm{hrs}$ and $48 \mathrm{hrs}$.Negative cultures were followed up by examining the broth daily for 10 consecutive days. Growth if any was identified by standard bacteriological techniques including gram staining, colony characteristics and biochemical reactions. Antibiotic sensitivity was tested as per recommended guidelines.

Results

\begin{tabular}{|l|c|c|c|}
\hline \multirow{2}{*}{ Organism } & \multicolumn{2}{|c|}{ Age } & \multirow{2}{*}{ Total } \\
\cline { 2 - 3 } & 1month-6yrs & 6-12yrs & \\
\hline No growth & 44 & 26 & 70 \\
\hline Cons & 14 & 2 & 16 \\
\hline Acinetobacter & 1 & 0 & 1 \\
\hline Enterobacter & 1 & 0 & 1 \\
\hline Pseudomonas & 1 & 0 & 1 \\
\hline E. coli & 2 & 0 & 2 \\
\hline Streptococcus pyogenes & 2 & 1 & 3 \\
\hline MRSA & 4 & 1 & 5 \\
\hline Candida & 1 & 0 & 1 \\
\hline Total & 70 & 30 & 100 \\
\hline
\end{tabular}

Table 1: Growth of organisms in Blood culture.

\begin{tabular}{|c|c|c|c|c|c|c|c|c|c|c|c|c|c|c|}
\hline & $\begin{array}{c}\text { Amika- } \\
\text { cin }\end{array}$ & $\begin{array}{l}\text { Genta- } \\
\text { mycin }\end{array}$ & $\begin{array}{c}\text { Cipro- } \\
\text { floxacin }\end{array}$ & $\begin{array}{c}\text { Ceftazi- } \\
\text { dime }\end{array}$ & $\begin{array}{l}\text { Erythro- } \\
\text { mycin }\end{array}$ & $\begin{array}{l}\text { Ampi- } \\
\text { cillin }\end{array}$ & $\begin{array}{c}\text { Clind } \\
\text { amycin }\end{array}$ & $\begin{array}{l}\text { Cotri- } \\
\text { moxa- } \\
\text { zole }\end{array}$ & $\begin{array}{c}\text { Spar- } \\
\text { floxa- } \\
\text { cin }\end{array}$ & $\begin{array}{l}\text { Cepha- } \\
\text { lexin }\end{array}$ & $\begin{array}{l}\text { Cefox- } \\
\text { itin }\end{array}$ & $\begin{array}{l}\text { Ceftri- } \\
\text { axone }\end{array}$ & $\begin{array}{l}\text { Cefo- } \\
\text { pera- } \\
\text { zone }\end{array}$ & $\begin{array}{c}\text { Cefo- } \\
\text { taxime }\end{array}$ \\
\hline Cons & $\begin{array}{c}9 \\
(30)\end{array}$ & $\begin{array}{c}6 \\
(20 \%)\end{array}$ & $\begin{array}{c}5 \\
(16.6 \%)\end{array}$ & $\begin{array}{c}1 \\
(3.33 \%)\end{array}$ & $\begin{array}{c}4 \\
(13.33)\end{array}$ & $\begin{array}{c}6 \\
(20 \%)\end{array}$ & $\begin{array}{c}4 \\
(13.33)\end{array}$ & $\begin{array}{c}1 \\
(3.33 \%)\end{array}$ & $\begin{array}{c}1 \\
(3.33 \%)\end{array}$ & $\begin{array}{c}5 \\
(16.6 \%)\end{array}$ & $\begin{array}{c}3 \\
(10 \%)\end{array}$ & $\begin{array}{c}0 \\
(0 \%)\end{array}$ & $\begin{array}{c}1 \\
(3.33 \%)\end{array}$ & $\begin{array}{c}1 \\
(3.33 \%)\end{array}$ \\
\hline $\begin{array}{l}\text { Acineto- } \\
\text { bacter }\end{array}$ & $\begin{array}{c}0 \\
(0 \%)\end{array}$ & $\begin{array}{c}1 \\
(3.33 \%)\end{array}$ & $\begin{array}{c}0 \\
(0 \%)\end{array}$ & $\begin{array}{c}0 \\
(0 \%)\end{array}$ & $\begin{array}{c}0 \\
(0 \%)\end{array}$ & $\begin{array}{c}0 \\
(0 \%)\end{array}$ & $\begin{array}{c}0 \\
(0 \%)\end{array}$ & $\begin{array}{c}1 \\
(3.33 \%)\end{array}$ & $\begin{array}{c}0 \\
(0 \%)\end{array}$ & $\begin{array}{c}0 \\
(0 \%)\end{array}$ & $\begin{array}{c}0 \\
(0 \%)\end{array}$ & $\begin{array}{c}0 \\
(0 \%)\end{array}$ & $\begin{array}{c}0 \\
(0 \%)\end{array}$ & $\begin{array}{c}0 \\
(0 \%)\end{array}$ \\
\hline $\begin{array}{l}\text { Entero- } \\
\text { bacter }\end{array}$ & $\begin{array}{c}1 \\
(3.33 \%)\end{array}$ & $\begin{array}{c}1 \\
(3.33 \%)\end{array}$ & $\begin{array}{c}0 \\
(0 \%)\end{array}$ & $\begin{array}{c}0 \\
(0 \%)\end{array}$ & $\begin{array}{c}0 \\
(0 \%)\end{array}$ & $\begin{array}{c}0 \\
(0 \%) \\
\end{array}$ & $\begin{array}{c}0 \\
(0 \%)\end{array}$ & $\begin{array}{c}0 \\
(0 \%)\end{array}$ & $\begin{array}{c}1 \\
(3.33 \%)\end{array}$ & $\begin{array}{c}0 \\
(0 \%)\end{array}$ & $\begin{array}{c}0 \\
(0 \%)\end{array}$ & $\begin{array}{c}0 \\
(0 \%) \\
\end{array}$ & $\begin{array}{c}0 \\
(0 \%) \\
\end{array}$ & $\begin{array}{c}0 \\
(0 \%) \\
\end{array}$ \\
\hline $\begin{array}{l}\text { Pseudo- } \\
\text { monas }\end{array}$ & $\begin{array}{c}1 \\
(3.33 \%)\end{array}$ & $\begin{array}{c}0 \\
(0 \%) \\
\end{array}$ & $\begin{array}{c}1 \\
(3.33 \%)\end{array}$ & $\begin{array}{c}1 \\
(3.33 \%)\end{array}$ & $\begin{array}{c}0 \\
(0 \%)\end{array}$ & $\begin{array}{c}0 \\
(0 \%) \\
\end{array}$ & $\begin{array}{c}0 \\
(0 \%)\end{array}$ & $\begin{array}{c}0 \\
(0 \%)\end{array}$ & $\begin{array}{c}0 \\
(0 \%) \\
\end{array}$ & $\begin{array}{c}0 \\
(0 \%)\end{array}$ & $\begin{array}{c}0 \\
(0 \%) \\
\end{array}$ & $\begin{array}{c}0 \\
(0 \%)\end{array}$ & $\begin{array}{c}0 \\
(0 \%) \\
\end{array}$ & $\begin{array}{c}0 \\
(0 \%) \\
\end{array}$ \\
\hline E. coli & $\begin{array}{c}0 \\
(0 \%) \\
\end{array}$ & $\begin{array}{c}2 \\
(6.66 \%) \\
\end{array}$ & $\begin{array}{c}0 \\
(0 \%)\end{array}$ & $\begin{array}{c}1 \\
(3.33 \%)\end{array}$ & $\begin{array}{c}0 \\
(0 \%)\end{array}$ & $\begin{array}{c}0 \\
(0 \%)\end{array}$ & $\begin{array}{c}0 \\
(0 \%) \\
\end{array}$ & $\begin{array}{c}1 \\
(3.33 \%)\end{array}$ & $\begin{array}{c}1 \\
(3.33 \%)\end{array}$ & $\begin{array}{c}0 \\
(0 \%)\end{array}$ & $\begin{array}{c}0 \\
(0 \%) \\
\end{array}$ & $\begin{array}{c}1 \\
(3.33 \%)\end{array}$ & $\begin{array}{c}0 \\
(0 \%) \\
\end{array}$ & $\begin{array}{c}0 \\
(0 \%) \\
\end{array}$ \\
\hline $\begin{array}{l}\text { Strepto- } \\
\text { coccus } \\
\text { pyo- } \\
\text { genes }\end{array}$ & $\begin{array}{c}1 \\
(3.33 \%)\end{array}$ & $\begin{array}{c}1 \\
(3.33 \%)\end{array}$ & $\begin{array}{c}0 \\
(0 \%)\end{array}$ & $\begin{array}{c}0 \\
(0 \%)\end{array}$ & $\begin{array}{c}0 \\
(0 \%)\end{array}$ & $\begin{array}{c}1 \\
(3.33 \%)\end{array}$ & $\begin{array}{c}1 \\
(3.33 \%)\end{array}$ & $\begin{array}{c}0 \\
(0 \%)\end{array}$ & $\begin{array}{c}0 \\
(0 \%)\end{array}$ & $\begin{array}{c}0 \\
(0 \%)\end{array}$ & $\begin{array}{c}0 \\
(0 \%)\end{array}$ & $\begin{array}{c}1 \\
(3.33 \%)\end{array}$ & $\begin{array}{c}1 \\
(3.33 \%)\end{array}$ & $\begin{array}{c}0 \\
(0 \%)\end{array}$ \\
\hline Mrsa & $\begin{array}{c}3 \\
(10 \%) \\
\end{array}$ & $\begin{array}{c}2 \\
(6.66 \%)\end{array}$ & $\begin{array}{c}3 \\
(10 \%) \\
\end{array}$ & $\begin{array}{c}1 \\
(3.33 \%)\end{array}$ & $\begin{array}{c}2 \\
(6.66 \%)\end{array}$ & $\begin{array}{c}1 \\
(3.33 \%)\end{array}$ & $\begin{array}{c}2 \\
(6.66 \%)\end{array}$ & $\begin{array}{c}0 \\
(0 \%)\end{array}$ & $\begin{array}{c}0 \\
(0 \%) \\
\end{array}$ & $\begin{array}{c}1 \\
(3.33 \%)\end{array}$ & 0 & $\begin{array}{c}2 \\
(6.66 \%)\end{array}$ & $\begin{array}{c}0 \\
(0 \%)\end{array}$ & $\begin{array}{c}1 \\
(3.33 \%)\end{array}$ \\
\hline Candida & $\begin{array}{c}0 \\
(0 \%) \\
\end{array}$ & $\begin{array}{c}0 \\
(0 \%) \\
\end{array}$ & $\begin{array}{c}0 \\
(0 \%) \\
\end{array}$ & $\begin{array}{c}0 \\
(0 \%) \\
\end{array}$ & $\begin{array}{c}0 \\
(0 \%) \\
\end{array}$ & $\begin{array}{c}0 \\
(0 \%) \\
\end{array}$ & $\begin{array}{c}0 \\
(0 \%) \\
\end{array}$ & $\begin{array}{c}0 \\
(0 \%) \\
\end{array}$ & $\begin{array}{c}0 \\
(0 \%) \\
\end{array}$ & $\begin{array}{c}0 \\
(0 \%) \\
\end{array}$ & $\begin{array}{c}0 \\
(0 \%) \\
\end{array}$ & $\begin{array}{c}0 \\
(0 \%) \\
\end{array}$ & $\begin{array}{c}0 \\
(0 \%) \\
\end{array}$ & $\begin{array}{c}0 \\
(0 \%) \\
\end{array}$ \\
\hline Total & 15 & 13 & 9 & 4 & 6 & 8 & 7 & 3 & 3 & 6 & 3 & 4 & 2 & 2 \\
\hline
\end{tabular}

Table 2: Results of antibiotic sensitivity. 


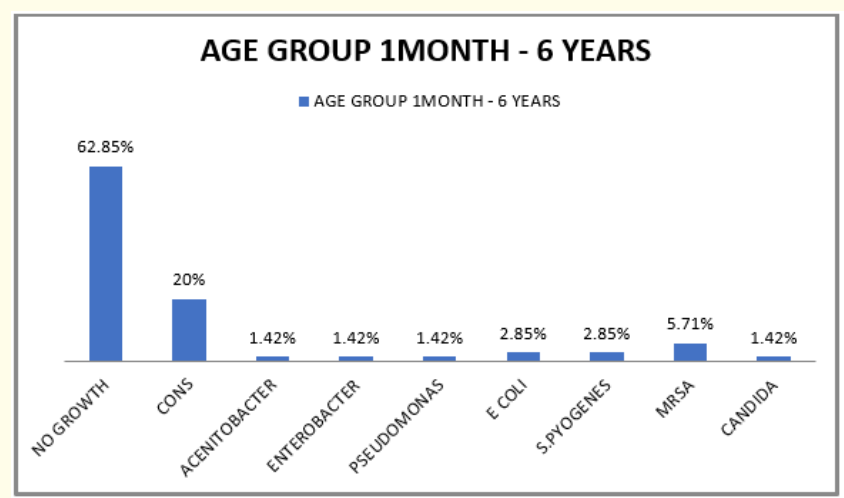

Figure 1: Growth of organisms in Blood culture.

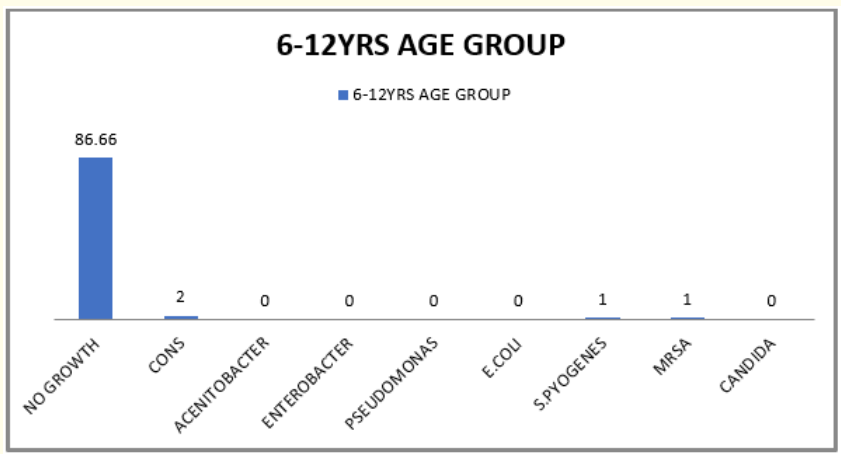

Figure 2: Predominant organisms in Age group 6 years to 12 years.

Of the 100 patients $30(30 \%)$ patients showed culture positivity.70 patients were from 1 month to 6 years out of which 26 $(37.14 \%)$ showed culture positivity in whom Coagulase negative Staphylococcus (CONS) was the predominant organism 14 (20\%), followed by Methicillin resistant Staphylococcus aureus (MRSA) 4 (5.71\%), followed by E. coli 2 (2.85\%) and Streptococcus pyogenes 2 (2.85\%) (Table 1 and figure 1). 30 patients were from the age group 6 years to 12 years out of which $4(13.33 \%)$ were culture positive in whom Coagulase negative Staphylococcus (CONS) was the predominant organism 2 (6.66\%) followed by Streptococcus pyogenes $1(3.33 \%)$ and Methicillin resistant Staphylococcus aureus (MRSA) $1(3.33 \%)$ (Table 1 and figure 2 ).

The results of the antibiotic sensitivity testing (Table 2 ) revealed that most of the isolates were sensitive to Amikacin.

\section{Discussion}

This study was conducted in order to determine the predominant organisms causing septicaemia in the two age groups and their antibiotic sensitivity pattern in our hospital.

Coagulase-negative staphylococci are now being recognized as a common cause of nosocomial infections in intensive care units, even though not all positive blood cultures of CONS represent true septicaemia because CONS in the skin flora commonly causes contamination of blood cultures [10]. In the present study gram positive bacteria were the most predominant isolates, among which Coagulase negative Staphylococcus (CONS) [1 month to 6 years $14(20 \%)$ and 6 years to 12 years $2(6.66 \%)]$ however similar results were noticed by others [10-12]. Paediatric oncology patients (mainly leukaemia and lymphoma), bone marrow transplant recipients, and children with burns are at high risk for acquiring CONS bloodstream infections [13,14]. CONS infections represent 35 to 40 per cent of all bacteraemia in febrile neutropenic cancer patients undergoing treatment $[14,15]$. Patients with an indwelling medical device such as a central venous catheter (CVC), ventriculoperitoneal shunt, peritoneal dialysis catheter, prosthetic valve, prosthetic joint, vascular graft and prosthesis, haemodialysis shunt, pacemaker, or scalp electrode are prone to develop CONS infections. Though CONS is usually considered as a skin contaminant the presence of this bacteria in blood in critically ill children should be treated especially 3 days after admission with an indwelling catheter in place [16].

The antibiotics which were used were based on the standard protocol of the hospital and our department policies, which are changed regularly pending the culture reports and infectious committee recommendations. The other causative organisms were MRSA 4 (5.71\%), E. coli 2 (2.85\%) and Streptococcus pyogenes 2 $(2.85 \%)$ in children between 1 month to 6 years. MRSA 1 (3.33\%) and Streptococcus pyogenes 1 (3.33\%) in children between 6 years to 12 years. The antibiotic sensitivity varies at different times in the same hospital due to the emergence of resistant organism as a result of unregulated use of antibiotics. This can be avoided by the usage of a drug to which the organism is susceptible. From this study, it was suggested that the empirical treatment should consist of Amikacin until the findings of culture and sensitivity are done, as most of the organisms found in our PICU were sensitive to Amikacin. 


\section{Conclusion}

The commonest organism causing sepsis in PICU is Coagulase negative Staphylococcus and this organisms have shown sensitivity to Amikacin.

The microbial aetiology of septicaemia is diverse. Thus, every PICU in charge should emphasize the mortal importance of a regular periodic testing of the microbial bacterial spectrum and their sensitivity to drugs in order to formulate a standard antibiotic regimen for PICU.

\section{Bibliography}

1. Nelson DS., et al. "Spectrum and frequency of paediatric illness presenting to a general community hospital emergency department". Paediatrics 90 (1992): 5-10.

2. Massin MM., et al. "Spectrum and frequency of illness presenting to a paediatric emergency department". Acta Clinica Belgica 61 (2006): 161-165.

3. Wald ER and Minkowski JM. "Bacteraemia in childhood". South Medical Journal 70 (1980): 904-905.

4. Wenzel RP., et al. "Current understanding of sepsis". Clinical Infectious Diseases 22 (1996): 407-412.

5. Wheeler AP and Bernard GR. "Treating patient with severe sepsis". The New England Journal of Medicine 340 (1999): 207214.

6. Gill J., et al. "Methicillin-resistance Staphylocicus aureus: awareness and perceptions". Journal of Hospital Infection 62 (2006): 330-337.

7. Blomberg B., et al. "Antimicrobial resistance predicts death in Tanzanian children with bloodstream infections: a prospective cohort study". BMC Infectious Diseases 7 (2007): 43.

8. Orrett FA and Changoor E. "Bacteremia in children at a regional hospital in Trinidad". International Journal of Infectious Diseases 11 (2007): 145-151.

9. Cosgrove SE., et al. "Comparision of mortality associate with Methcillin suscipitable Staphylococcus aureus bacteremia: a meta analysis". Clinical Infectious Diseases 36 (2003): 53-59.

10. Huang Shi-Ying., et al. "Coagulase-Negative Staphylococcal Bacteremia in Critically ill Children? Risk Factors and Antimicrobial Susceptibility". Journal of Microbiology, Immunology and Infection 36 (2003): 51-55.
11. Wisplinghoff., et al. "Nosocomial bloodstream infections in pediatric patients in United States hospitals: epidemiology, clinical features and susceptibilities". Pediatric Infectious Disease Journal 22.8 (2003): 686-691.

12. Lucignano B., et al. "Multiplex PCR Allows Rapid and Accurate Diagnosis of Bloodstream Infections in Newborns and Children with Suspected Sepsis". Journal of Clinical Microbiology (2011): 2252-2258.

13. Santucci SG., et al. "Infections in a burn intensive care unit: experience of seven years". Journal of Hospital Infection 53 (2003): 6-13.

14. Langley J and Gold R. "Sepsis in febrile neutropenic children with cancer". Pediatric Infectious Disease Journal 7 (1988): 3437.

15. Celkan T., et al. "Bacteremia in childhood cancer". Journal of Tropical Pediatrics 48 (2002): 373-377.

16. J P Buttery. "Blood cultures in newborns and children: optimising an everyday test". Archives of Disease in Childhood. Fetal and Neonatal Edition 87 (2002): 25-28. 